\title{
UK contributions to famine relief
}

\author{
By R. G. Whitehead, University of Cambridge and Medical Research Council, \\ Dunn Nutrition Unit, Milton Road, Cambridge $\mathrm{CB}_{4} \mathrm{x} X \mathfrak{F}$
}

The nature and extent of the UK's contributions to famine relief must be viewed in the light of our changing role in international affairs. There was a time when Britain had executive authority over countries where periodic famines were prevalent, but these times are long past and it is important that we should recognize this. In nutritional aid, as in other types of aid, our policy must be to concentrate on assisting others to help themselves.

\section{Postgraduate training schemes}

It is for this reason that I am beginning my paper by stressing the important contribution which British postgraduate training in applied nutrition can make to this problem. This might seem a very tame type of assistance to those who have been concerned with the responsibilities of handling emergency situations, but we will continue to have such emergencies until the underlying problems have been dealt with on a long-term basis. While I have no doubt that there will be a continuing role for at least some British expatriate experts for many years, the major effort must come from within, from nutrition workers who are nationals of the country in trouble. Making certain such people have an adequate training is a very important responsibility.

One must question, however, whether a European country like the UK is the best place to organize the type of wide-ranging instruction necessary to deal with a problem as great as the relief of famine. The advantage of holding courses here is that we have available a corps of lecturers with experience gained in many different countries and under different circumstances and thus the training does not run the risk of being too parochial, too dominated by one particular philosophy or the specific problems of a single country. On the other hand, it is difficult to provide the sort of on-the-spot practical experience which is essential for this type of training.

To my mind the scheme operated for a short time at the London School of Hygiene and Tropical Medicine, whereby students spent part of their time in London and the remainder in Africa was an excellent, even if expensive, compromise. It would, I feel, be money well spent if the UK could reintroduce something along these lines. There are various ways in which it could be done: through integrated teaching links with overseas universities, for example.

What is essential is that the training is designed to provide the student with a balanced over-all view of the problem. The existing skills of the doctors, laboratory workers, economists, agriculturalists, veterinarians and sociologists taking such courses will continue to be required, but they need to be shown how to organize 
their work in the context of the whole multiplicity of factors which can give rise to malnutrition in a country.

One example of an attempt to mount a course based entirely within the UK was the Institute of Development Studies Seminars held at the University of Sussex in 1971, and again in 1974. Each was attended by eighteen to twenty overseas participants, most of whom were funded by the Ministry of Overseas Development (ODM). These seminars were intended for senior personnel, up to Under-Secretary rank, and the aim was to encourage planners at the highest level to introduce nutritional considerations into their social developmental planning. The participants were from varied backgrounds and included agricultural and medical officers, economists and food scientists, as well as administrators with no previous scientific experience. It was clearly the hope that the training of these top people would lead to the subsequent stimulation of more junior planners, followed by some form of action; but the over-all effectiveness of courses of this type still needs to be established.

\section{Creating career opportunities for nutritional specialists}

The provision of specialized training can only be effective if it is linked with job opportunities for the students when they return home. It is apparent that the value of much of the training provided by the UK is lost for this reason, a fact which has not escaped the attention of both the organizations providing the training and the grant-giving bodies. It is not unlikely that in the future, priority in training within the UK will be given to those countries which have a well-planned nutritional developmental programme containing posts designated for those whom the country claims it wishes to be trained. The UK does provide and should continue to provide aid to enable the necessary staffing changes to be initiated.

\section{Food and nutrition aid by the British Government}

Apart from training, Britain is quite heavily involved in providing more direct aid, from both governmental sources and through charitable bodies. These activities come most to the public notice during nutritional crises; indeed, these provide the charities with their major source of funds, but it is important that the glamour of such events is not allowed to detract from the much more important task of initiating long-term prevention. This is said not to decry the intense activity which goes on in Britain to relieve suffering at these times, but to warn against the development of a stop-go policy in the relief of famine.

For an insight into present British Government thinking, an important recently published document is the Report of the Overseas Development Agency Advisory Committee on Protein (Overseas Development Agency, 1974). One of the tasks of this committee was to advise on ways, within her aid programme, by bilateral or multilateral action, in which the British Government could improve our overseas nutritional aid programmes. I am advised that this report now forms the basis of the Ministry's policy and thus its contents are well worth examining in some detail.

Part of the document is taken up with a scientific discussion about protein-energy interrelationships, man's requirements for these nutrients and 
changing ideas about the causes of kwashiorkor and marasmus, but this lies outside the scope of this meeting and the most relevant sections are those concerned with what the committee felt were the root causes of malnutrition. The committee examined this from a number of standpoints, including dietary intake, nutrition-infection interrelationships and the influence of social and cultural factors, and they summarized their views in the diagram reproduced in Fig. I. It can be seen that in spite of the many complexities involved, poverty and a failure of income to meet dietary needs was at the back of the problem in most countries. There are obviously exceptions to this generalization; not all poor people in a country become malnourished, but nevertheless malnutrition is primarily a problem of the poor.

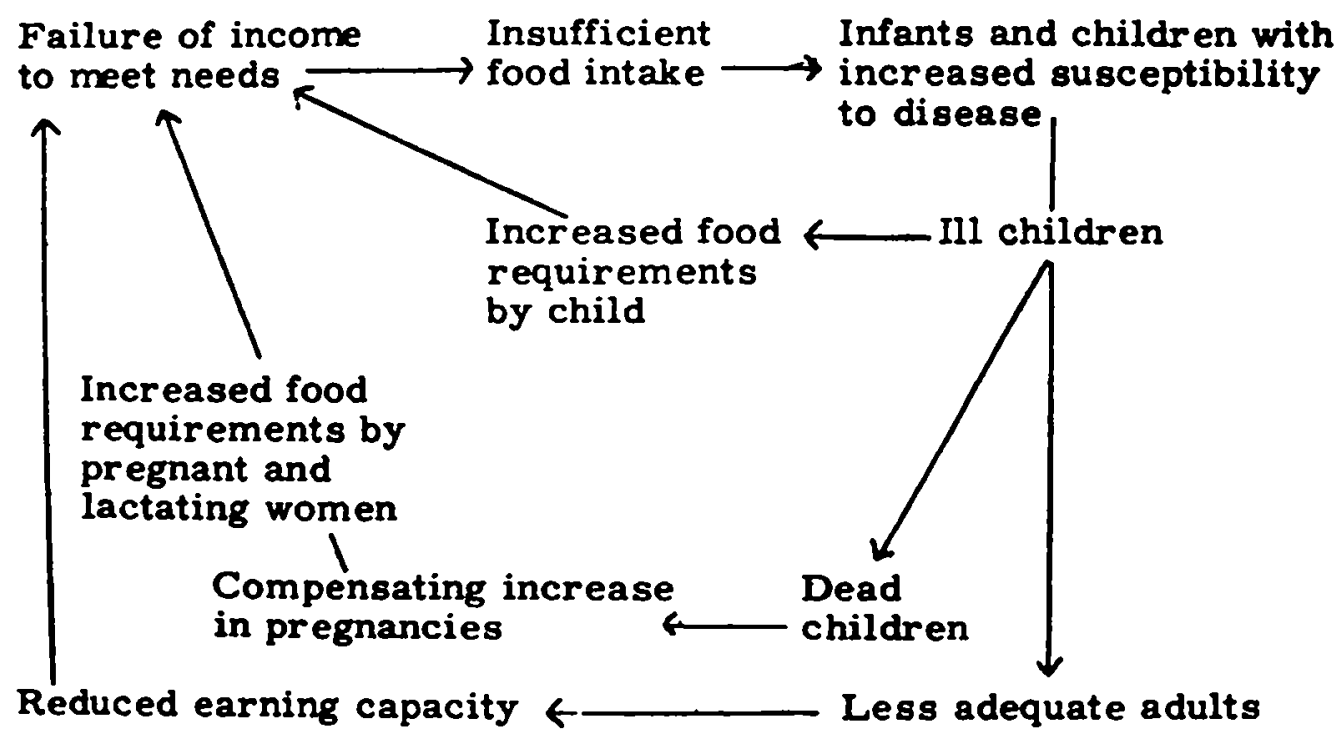

Fig. I. Interrelationships between various factors leading to malnutrition and their link with poverty. From Overseas Development Agency (1974).

The committee advised ODM that the primary attack on malnutrition should be through the alleviation of poverty. They were conscious that economic advance by itself does not necessarily produce this effect unless the distribution of wealth favours the poor, and their basic recommendation was that in the interests of better nutrition, aid should be directed towards projects that will generate income among the poor, even where such projects do not have any marked effect on the national income of the country concerned'.

This policy recommendation is in many ways quite revolutionary and indeed, if it does become accepted British Government policy, it will result in a quite new approach in agricultural aid, for example. The committee pointed out that increased food supplies often do not benefit the rural poor because developmental aid has concentrated on the most productive land. They recommend that more attention should be given to less productive farming areas, even very marginal ones, for only in this way could one be sure of benefiting the poorer farmers. 
This ODM committee report is welcome for a variety of reasons. It places the relief of malnutrition and famine where it should be, in long-term economic development to aid directly the people who need it most. The danger, however, is that the approach is ahead of its time and it might frighten planners of a more traditional frame of mind. This could inhibit rather than accelerate progress.

The 1974 World Food Conference in Rome also had an impact on British Government policy and planning. The Minister for Overseas Development has affirmed in an unequivocal manner that Britain supports the need for increased grain and dairy production by the richer countries on behalf of the poorer ones, coupled with an effective and planned stockholding system. This is essential for emergency relief; there is little point in providing crisis money for food aid if there is no spare food in store.

Britain, as a member of the World Food Council set up by the UN General Assembly following the Rome Conference, is actively reviewing the contribution which she and the other European Economic Community (EEC) countries can make to implement the special proposal that a new agricultural fund should be set up. Only the major grain-producing countries can reasonably be expected to provide the great excess of grain required, but other countries can help by financing what would otherwise be a commercially uneconomic venture.

Another way in which the richer countries can help is by economizing on their own utilization of imported grain for animal feeds. Already, because of balance of payments problems, the Ministry of Agriculture, Fisheries and Food has been strongly urging the greater use of free-range farming and less dependence on imported animal feed. In addition, the European Commission have largely eliminated subsidies, in the form of export refunds, for pig meat and poultry, the production of which makes a major demand on cereals. Both these measures should make more grain available for human consumption. This is certainly what ODM hopes.

On first examination these latter moves might seem to be minor ones, but if extended further for humanitarian reasons they would have a profound effect on British agricultural technology. They would almost certainly lead to a reduced yield and therefore more expensive meat within the UK; Britain would be sacrificing farming efficiency in the cause of an international food policy. It will be a major break-through in human relations if such policies can be made to stick. İt is not unreasonable to comment, however, that the developing countries must also prove themselves capable of responding efficiently to such sacrifices. It is little encouragement to know that food aid can be misappropriated by corrupt practices.

These are concepts for the future; what is the British Government actually doing now about the relief of famine? Recently ODM have prepared a summary of their activities and I am grateful to them for letting me reproduce some of the facts.

In the financial year ending April 1975, ODM anticipated they would have spent nearly $£ 20$ million on food aid. Most of this aid was provided as a co-operative venture with other countries of the EEC. During the run of crises in recent months this community aid has gone mainly to the Sahel, India and Bangladesh. 
Britain is also a major regular contributor to the World Food Programme: at the end of January 1975 an additional grant of $f_{5} 5$ million was made to the Programme, specially earmarked for Bangladesh.

In order to be able to respond more quickly and effectively when crises occur, the Minister for Overseas Development recently established a Disaster Unit. One of the purposes of this unit is to keep a watch on developing famine situations and to identify sources of supply in advance. The unit has also recognized that logistic problems often inhibit effective and instant action and thus they have built up a reserve of lorries and other vehicles which are held in readiness to be delivered to disaster areas at a moment's notice. Examples during 1974-5 of such emergency actions are summarized in Table $\mathbf{r}$.

Table 1. UK Ministry of Overseas Development response to famine emergencies in 1974

Bangladesh

Ethiopia

Sahel Zone

Somalia
Food (48000 t); waterways transport; drugs and medicines, additional aid funds to maintain essential imports (not all spent yet); total value of help for relief, rehabilitation and development, 674 million in the 3 years' existence of the country.

Spring and summer 1974: famine relief of 6350000 including food-for-work projects, restocking herds; fifty trucks for distribution of emergency supplies; road- and bridge-building with help of the Royal Engineers.

Joint assistance with voluntary agencies; TransSahara Army relief convoy: 10000 t food to Mali, trucks and grain air-lifted to Chad and Niger.

December 1974: appeal for emergency help in drought situation; $17 \mathrm{t}$ wheat flour, $18 \mathrm{t}$ skim-milk powder, 120 portable water-containers flown in.

\section{Aid from the charitable bodies}

Apart from governmental action, various charitable bodies play a major role in Britain's famine-aid programme. These, too, make contributions both to crisis situations and to more long-term nutrition-aid programmes, but since their major funding is attracted by the former, and because ODM's future main contribution is to be towards long-term programmes, it seems that in the future the charitable bodies could act most profitably and efficiently on specific problems of immediate importance. In fact, ODM are already channelling a significant proportion of their emergency aid through these charities, as can be seen from Table I.

One major advantage that the charitable bodies often have over ODM is that it is possible for them to consider and act on specific problems more speedily; they are not bound quite so tightly by diplomatic protocol. The fact that there are a number of charities with separate organizational committees is also an advantage, as they tend to be attracted by different types of problem: thus the ground can be covered more completely. 
Some amount of co-ordination of activities is, of course, necessary and since 1964 there has been a Disaster Emergency Committee now comprising the British Red Cross Society, Christian Aid, Catholic Fund for Overseas Development, Oxfam, Save the Children Fund and War on Want. The prime function of this committee is to act as an agency for appeals for the five main British charities concerned with overseas relief. The success of television appeals for raising money had been leading to intense rivalry between the charities and the idea of joint action was proposed by the late Lord Astor. Each charity is allocated one-fifth of the appeal proceeds but is completely responsible for the expenditure of its own share. The member charities meet frequently, however, to decide how best the money can be spent, based on information received from the country directly concerned through Government, Red Cross and other reliable channels. Some idea of the amounts of money raised from disaster appeals can be gained from Table 2.

Table 2. Some results from UK radio and television appeals for famine relief

\begin{tabular}{|c|c|c|c|}
\hline & & & $£$ \\
\hline I973 & Ethiopia and Sahel & $\begin{array}{l}\text { BBC: Jonathan Dimbleby } \\
\text { ITN: Jonathan Dimbleby }\end{array}$ & 1541407 \\
\hline I97I & India and Pakistan & $\begin{array}{l}\text { BBC: Ludovic Kennedy } \\
\text { ITN: Robert Kee }\end{array}$ & I 405325 \\
\hline 1970 & Pakistan & BBC: Richard Attenborough & 1485000 \\
\hline 1969 & Algeria and Tunisia & $\begin{array}{l}\text { BBC: Kenneth Kendall } \\
\text { ITN: Andrew Gardner }\end{array}$ & 89405 \\
\hline 1968 & Nigeria & $\begin{array}{l}\text { BBC: Nicholas Stacey } \\
\text { ITN: Peter Snow }\end{array}$ & $24 \times 847$ \\
\hline
\end{tabular}

This by no means represents the total expenditure of the charities, but it is not possible to provide an absolute value as it is difficult to separate food and famine aid from other types of assistance during emergencies.

The already significant sums at their disposal, plus the increased co-operation with the British Government, has encouraged the charitable bodies to look critically at the efficiency and the ultimate achievements of their various operations. In this connexion an important initiative has recently been taken by $\mathrm{Dr}$ Katherine Elliott, of the CIBA Foundation, in which officials of the charities and various academics specializing in the prevention and treatment of malnutrition have been brought together to discuss different approaches to famine relief. This type of association needs every encouragement.

I have already said that in Britain there is a considerable corps of expertise on the nutritional problems of the developing countries which could be used to greater effect. My own laboratory was able to second to Oxfam two staff members for field work in Ethiopia (Mason, Hay, Holt, Seaman \& Bowden, 1974; Mason, Hay, Leresche, Peel \& Darley, 1974) and other departments have been able to do the same. One might hope that ultimately it would be possible to make a group of more regular 'nutritional ever-readies' (for the want of a better term) available, who could be called upon for specific advice and assistance in famine crises. 
Mason, J. B., Hay, R. W., Holt, J., Seaman, J. \& Bowden, M. R. (1974). Nature, Lond. 248, 646. Mason, J. B., Hay, R. W., Leresche, J., Peel, S. \& Darley, S. (1974). Lancet i, 332.

Overseas Development Agency (1974). Report of the Overseas Development Agency Advisory Committee on Protein. London: Ministry of Overseas Development. 